Volume 1 Issue 1, January 2022: pp. 76-83 Copyright @ NoLaJ.

Master of Notary, Faculty of Law, Lambung Mangkurat University,

Banjarmasin, South Kalimantan, Indonesia. ISSN: 2808-7860 | e-ISSN: 2808-7348

Open Access at: https://notarylaw.journal.ulm.ac.id/index.php/nolaj

\title{
Kedudukan Hukum Hak Kepemilikan atas Tanah yang Berasal dari Proses Pengendapan Arus Sungai (Delta) dalam Perspektif Hukum Pertanahan di Indonesia
}

\author{
Rabiatul Adawiyah \\ Law Office and Legal Consultant \\ Komp.Wildan Sari No 45 Kel. Telaga Biru. Kec. Banjarmasin Barat, Kota Banjarmasin, \\ Kalimantan Selatan, Indonesia 70119 \\ Email: rabiatul011288@gmail.com
}

Submitted : 18-10-2021 Reviewed:31-10-2021 Accepted:04-11-2021

\begin{abstract}
The goals of this research are to study the regulation on the legal position of ownership right upon land originating from river current sedimentation process (delta), and to study what kind of right which can be adhered to the land originating from river current sedimentation process (delta). This is normative legal research in the research is started by making inventory of the legislation, court verdicts, other regulations and references related with ownership right upon a piece of land originating from river current sedimentation process (delta) for later implementation in actual cases in the society. Regulation on the land originating from river current sedimentation process (delta) has not yet been regulated, so there is vacuum of law. This vacuum of law has resulted many legal problems regarding ownership right upon land originating from river current sedimentation process (delta). The results of this research show that the regulation on the ownership right upon land originating from river current sedimentation process (delta) has not yet been regulated, so there is vacuum of law. Such delta land can be categorized the same as emerging land (aanslibbing) and the form of the right which can be adhered to the land originating from river current sedimentation process (delta) is ownership right, right to use, and right to build.
\end{abstract}

Keywords: Regulation; Rights on Delta land; Vacuum of law

\begin{abstract}
Abstrak:Tujuan dari penelitian ini adalah untuk mengkaji pengaturan kedudukan hukum hak kepemilikan terhadap bidang tanah yang berasal dari proses pengendapan arus sungai (delta) dan untuk mengkaji bentuk hak apa saja yang bisa dilekatkan terhadap bidang tanah yang berasal dari proses pengendapan arus sungai (delta). Penelitian ini merupakan suatu penelitian hukum normatif, dimana penelitian hukum yang dilakukan oleh peneliti dimulai dengan menginventarisasi peraturan perundang-undangan, putusan hakim, pengaturan maupun referensi lain terkait dengan Hak Milik terhadap bidang tanah yang berasal dari proses pengendapan arus sungai (delta) untuk kemudian diterapkan dalam kasus yang terjadi di masyarakat. Pengaturan yang mengatur tentang bidang tanah yang berasal dari proses pengendapan arus sungai (delta) belum diatur sehingga terdapat kekosongan hukum. Kekosongan hukum ini mengakibatkan timbulnya banyak
\end{abstract}


permasalahan hukum berkenaan dengan Hak Milik atas bidang tanah delta tersebut. Hasil dari penelitian ini adalah pengaturan yang mengatur tentang bidang tanah yang berasal dari proses pengendapan arus sungai (delta) belum diatur sehingga terdapat kekosongan hukum namun karena keberadaan tanah yang berasal dari proses pengendapan arus sungai (delta) itu ada maka, tanah delta tersebut dapat dikategorikan sama seperti tanah timbul (aanslibbing) dan bentuk hak yang bisa dilekatkan terhadap bidang tanah yang berasal dari proses pengendapan arus sungai (delta) adalah Hak Milik, Hak Pakai dan Hak Guna Bangunan.

Kata Kunci: Hak-hak atas Tanah Delta; Kekosongan Hukum; Pengaturan.

\section{PENDAHULUAN}

Dalam peraturan perundang-undangan di bidang pertanahan diatur salah satu terjadinya hak atas tanah adalah hak atas tanah terjadinya menurut hukum adat yakni Hak Milik. Menurut Pasal 22 ayat (1) UUPA bahwa: Terjadinya hak Hak Milik menurut Hukum Adat itu diatur dengan Peraturan Pemerintah, akan tetapi Peraturan Pemerintah yang diperintahkan disini sampai pada saat ini belum juga dibuat. ${ }^{1}$ Terjadinya Hak Milik ini melalui pembukaan tanah dan lidah tanah. Yang dimaksud dengan lidah tanah adalah tanah yang timbul atau muncul karena berbeloknya arus sungai atau tanah yang timbul ditepi pantai atau juga disebut dengan tanah delta. ${ }^{2}$ Tanah ini berasal dari endapan lumpur yang semakin lama semakin meninggi kemudian mengeras. Timbulnya tanah ini bukan karena kesengajaan dari seorang atau pemilik tanah yang berbatasan, akan tetapi terjadi begitu saja atau lebih tepatnya terjadi secara alamiah. $^{3}$

Tanah delta adalah tanah datar hasil pengendapan yang dibentuk oleh sungai, muara sungai, dimana timbunan material sedimen tersebut mengakibatkan propagradasi yang tidak teratur pada garis pantai. ${ }^{4}$ Proses pembentukan tanah delta yang terdapat pada muara sungai dipengaruhi oleh suplai sedimen, proses fluvial, kestabilan tektonik, gelombang, arus dan pasang surut. $^{5}$

Sebagai daratan yang terbentuk karena adanya peristiwa alam, tanah timbul ini merupakan daratan yang memiliki potensi dan nilai ekonomis yang sangat bagus untuk dimanfaatkan, baik untuk usaha pertanian, tambak, maupun tempat untuk mendirikan bangunan. ${ }^{6}$ Akan tetapi sampai pada saat ini dalam hukum pertanahan di Indonesia belum ada ditemukan ketentuan yang mengatur secara eksplisit mengenai penguasaan dan kepemilikan atas tanah timbul seperti tanah delta oleh karena itu sebagai fenomena hukum, bagi peneliti sangat menarik untuk dikaji sistem penguasaan dan kepemilikan atas tanah timbul seperti tanah delta, demikian juga pengaturan terkait tanah timbul seperti tanah delta dalam perundang-undangan beserta

\footnotetext{
${ }^{1}$ Sudikno Merthokusumo, Hukum Dan Politik Agraria (Jakarta: Karunika Universitas Terbuka, 1988).

${ }^{2}$ Merthokusumo.

${ }^{3}$ Merthokusumo.

${ }^{4}$ Alif Akbar, "Studi Perubahan Garis Pantai Wulan Demak Jawa Tengah," Jurnal Hukum 3, no. 7 (2013): 1.

${ }^{5}$ Akbar.

${ }^{6}$ Rudiansyah Pulungan, "Status Penguasaan Tanah Timbul (Aanslibbing) Di Kecamatan Rengat Kabupaten Indragiri Hulu," Premise Law Jurnal 1, no. 2 (2013): 1, https://jurnal.usu.ac.id/index.php/premise/article/view/8247.
} 
langkah-langkah yang harus ditempuh untuk memperoleh hak atas tanah terkait penguasaannya. ${ }^{7}$ Tidak berlakunya Kitab Undang-Undang Hukum Perdata (Burgerlijk Wetboek, Staatsblad Tahun 1847 Nomor 23), ketidakjelasan UUPA dan tidak adanya Peraturan Pemerintah atau peraturan teknis lainnya menyebabkan terjadinya kekosongan hukum berkenaan dengan hak milik atas bidang tanah dari proses pengendapan arus sungai (delta). Sehingga dari kekosongan hukum ini mengakibatkan timbulnya banyak permasalahan hukum berkenaan dengan Hak Milik atas bidang tanah dari proses pengendapan arus sungai (delta) tersebut. Permasalahan hukum yang terjadi adalah pembatalan sertifikat hak atas tanah delta dan pelanggaran terhadap Hak Milik atas tanah delta yang dimasukkan dalam Perbuatan Melawan Hukum (PMH). Berdasarkan latar belakang diatas maka penulis membuat rumusan masalah sebagai berikut :Bagaimana pengaturan kedudukan hukum hak kepemilikan terhadap bidang tanah yang berasal dari proses pengendapan arus sungai (delta)? yang kedua Apakah bentuk hak yang bisa dilekatkan terhadap bidang tanah yang berasal dari proses pengendapan arus sungai (delta)?

\section{METODE PENELITIAN}

Jenis penelitian dalam penelitian ini merupakan penelitian hukum normatif. Penelitian hukum normatif adalah suatu proses untuk menemukan suatu aturan hukum, prinsip-prinsip hukum, maupun doktrin-doktrin hukum yang dihadapi dan penelitian ini dilakukan untuk menghasilkan argumentasi, teori atau konsep baru sebagai preskripsi penyelesaian masalah. ${ }^{8}$ Peter Mahmud Marzuki menjelaskan penelitian hukum normatif adalah:' Suatu proses untuk menemukan suatu aturan hukum, prinsip-prinsip hukum, maupun doktrin-doktrin hukum untuk menjawab permasalahan hukum yang dihadapi. Penelitian hukum normatif dilakukan untuk menghasilkan argumentasi, teori atau konsep baru sebagai preskripsi dalam menyelesaikan masalah yang sedang dihadapi.

Tipe penelitian dalam penelitian yang dilakukan adalah kekosongan hukum. Kekosongan hukum dapat didefinisikan menurut kamus hukum istilah populer adalah suatu keadaan kosong atau ketidakadaan peraturan perundang-undangan (hukum) yang mengatur dalam hal ini mengenai kedudukan hukum hak kepemilikan dari tanah proses pengendapan arus sungai (delta) yang ada di dalam masyarakat, ${ }^{10}$ sehingga kekosongan hukum dalam hukum positif lebih tepatnya dapat dikatakan sebagai kekosongan undang-undang/peraturan perundangundangan. ${ }^{11}$

Ilmu hukum mempunyai karakter yang khas, yaitu sifatnya yang normatif, praktis dan

\footnotetext{
7 Pulungan.

8 Peter Mahmud Marzuki, Penelitian Hukum (Surabaya: Kencana, 2011).

9 Marzuki.

${ }^{10}$ Jonaedi Efendi, Ismu Gunadi Widodo, and Fifit Fitri Luthfianingsih, Kamus Istilah Hukum Populer (Jakarta: Prenadamedia Group, 2016).

${ }^{11}$ Efendi, Widodo, and Luthfianingsih.
} 
preskriptif. ${ }^{12}$ Sebagai ilmu yang bersifat preskriptif, ilmu hukum mempelajari tujuan hukum, nilai-nilai keadilan, validitas aturan hukum, konsep-konsep hukum dan norma-norma hukum. Sebagai ilmu terapan, ilmu hukum menetapkan standar prosedur, ketentuan-ketentuan, rambu-rambu dalam melaksanakan aktivitas hukum. ${ }^{13}$ Penelitian yang dikaji peneliti dalam artikel ini merupakan penelitian yang bersifat preskriptif (apa yang seharusnya), yang dimaksudkan untuk memberikan argumentasi atas hasil yang telah dilakukan.

Pada penelitian ini, pendekatan yang dipakai adalah pendekatan perundang-undangan (statute approach), pendekatan konseptual (conceptual approach) dan pendekatan perbandingan (comparative approach). Pendekatan perundang-undangan (statute approach) yaitu dengan menelaah semua peraturan perundang-undangan yang bersangkut paut dengan permasalahan yang sedang dihadapi. ${ }^{14}$

Pendekatan perundang-undangan (statute approach) biasanya digunakan untuk meneliti peraturan perundang-undangan yang dalam penormaannya masih terdapat kekurangan atau malah menyuburkan praktek penyimpangan baik dalam tatanan teknis atau dalam pelaksanaannya di lapangan. ${ }^{15}$ Pendekatan konseptual (conceptual approach) yaitu suatu pendekatan yang digunakan untuk memperoleh kejelasan dan pembenaran ilmiah berdasarkan konsep-konsep hukum yang bersumber dari prinsip-prinsip hukum. ${ }^{16}$ Pendekatan konseptual (conceptual approach) ini sebagian dipakai untuk memahami konsep-konsep yang berkaitan dengan penormaan dalam suatu perundang-undangan apakah telah sesuai dengan ruh yang terkandung dalam konsep-konsep hukum yang mendasarinya. ${ }^{17}$ Menurut Gutteridge pendekatan perbandingan (comparative approach) adalah suatu metode studi dan penelitian hukum. ${ }^{18}$ Pendekatan perbandingan (comparative approach) merupakan jenis pendekatan yang peneliti mencoba untuk membandingkan baik dengan negara-negara lain maupun dengan peristiwa-peristiwa yang pernah terjadi dalam satu negara. ${ }^{19}$

Jenis bahan hukum dapat dibedakan menjadi tiga, yaitu bahan hukum primer, bahan hukum sekunder dan bahan hukum tertier.

Teknik pengumpulan bahan hukum dalam penelitian ini, dengan cara menginventarisir bahan hukum primer, bahan hukum sekunder dan bahan hukum tersier di atas yang terkait

\footnotetext{
${ }^{12}$ Philipus M.Hadjon and Tatiek Sri Djatmiati, Argumentasi Hukum (Yogyakarta: Gadjah Mada University Press, 2005).

${ }^{13}$ Marzuki, Penelitian Hukum.

${ }^{14}$ Marzuki.

${ }^{15}$ Saiful Anam, "Pendekatan Perundang-Undangan (Statute Approach) Dalam Penelitian Hukum," Siafulanam \& Partners: Advocates \& Legal Consultants, 2017, https://www.saplaw.top/pendekatan-perundang-undangan-statuteapproach-dalam-penelitian-hukum.

${ }^{16}$ Marzuki, Penelitian Hukum.

${ }^{17}$ Anam, "Pendekatan Perundang-Undangan (Statute Approach) Dalam Penelitian Hukum."

${ }^{18}$ G. W. A Paton, Textbook of Jurisprudence. English Language Book Society (London: Oxford University Press, 1972).

${ }^{19}$ Paton.
} 
dengan permasalahan hukum dalam penelitian ini, ${ }^{20}$ kemudian bahan hukum tersebut dipilah berdasarkan pokok bahasan guna menjawab segala permasalahan yang telah dirumuskan. ${ }^{21}$

Dalam tahap awal, peneliti mengumpulkan bahan hukum untuk selanjutnya menganalisis bahan hukum tersebut yang berkaitan dengan permasalahan yang dibahas serta mengaitkannya dengan teori hukum yang relevan, sehingga akhirnya akan memberikan hasil yang signifikan dan bermakna.

\section{III.ANALISIS DAN PEMBAHASAN}

\subsection{Pengaturan Kedudukan Hukum Hak Kepemilikan terhadap Bidang Tanah yang ber- asal dari Proses Pengendapan Arus Sungai (Delta)}

Persoalan-persoalan hukum mengenai tanah yang terjadi di Indonesia memang suatu hal yang sangat sensitif, tanah itu merupakan anugerah dari Tuhan Yang Maha Esa, bisa menjadi konflik yang berkepanjangan bahkan bisa terjadi pertumpahan darah dalam memperebutkannya, apalagi tanah timbul seperti tanah yang berasal dari proses pengendapan arus sungai (delta) ini dianggap sebagai "tanah yang tak bertuan" yang tiba-tiba saja muncul sebagai akibat dari suatu fenomena alam. Menurut Surat Edaran Menteri Negara Agraria/ Kepala Badan Pertanahan Nasional (BPN) Republik Indonesia Nomor: 410-1239 tanggal 9 Mei 1996 perihal Penertiban Status Tanah Timbul dan Tanah Reklamasi:

Tanah-tanah yang timbul secara alami seperti tepi pantai, tepi danau, endapan tepi sungai, pulau timbul dan tanah timbul secara alami lainnya dinyatakan sebagai tanah yang langsung dikuasai oleh negara, selanjutnya penguasaan/pemilikan serta penggunaannya diatur oleh Menteri Negara Agraria/Kepala Badan Pertanahan Nasional sesuai dengan perundang-undangan yang berlaku.

Menurut ayat 3 Surat Edaran Menteri Negara Agraria/Kepala Badan Pertanahan Nasional Nomor: 410-1293 tentang Penerbitan Status Tanah Timbul dan Tanah Reklamasi bahwa: Tanah-tanah timbul secara alami seperti tanah pantai, tepi danau/situ, endapan tepi sungai, pulau timbul dan tanah timbul secara alami lainnya dinyatakan sebagai tanah yang langsung dikuasai oleh Negara. Selanjutnya penguasaan/pemilikan serta penggunaannya diatur oleh Menteri Agraria/Kepala Badan Pertanahan Nasional sesuai dengan peraturan perundangundangan yang berlaku. ${ }^{22}$

Menurut Pasal 12 Peraturan Pemerintah Nomor 16 Tahun 2004 tentang Penatagunaan Tanah adalah: Tanah yang berasal dari tanah timbul atau hasil reklamasi di wilayah perairan pantai, pasang surut, rawa, danau dan bekas sungai dikuasai langsung oleh negara. Sehingga dengan demikian dapat diketahui bahwa secara Hukum Tanah Nasional, tanah timbul adalah tanah yang dikuasai langsung oleh Negara, ${ }^{23}$ oleh sebab itu setiap orang yang akan menguasai tanah timbul haruslah memperoleh izin terlebih dahulu dari aparat pemerintah

\footnotetext{
${ }^{20}$ Mukti Fajar Nur Dewata and Yulianto Achmad, Dualisme Penelitian Hukum Normatif Dan Empiris (Jakarta: Pustaka Pelajar, 2010).

${ }^{21}$ Dewata and Achmad.

${ }^{22}$ Pulungan, "Status Penguasaan Tanah Timbul (Aanslibbing) Di Kecamatan Rengat Kabupaten Indragiri Hulu."

${ }^{23}$ Pulungan.
} 
yang berwenang untuk itu yaitu Badan Pertanahan Nasional (Badan Pertanahan Nasional) Republik Indonesia Kabupaten/Kota setempat. ${ }^{24}$

Menurut Pasal 7 ayat (1) huruf g Undang-Undang Nomor 12 Tahun 2011 Tentang Pembentukan Peraturan Perundang-Undangan: Salah satu jenis dan hierarki peraturan perundang-undangan adalah Peraturan Daerah (Perda), oleh karena itu Perda secara langsung terintegrasi dari peraturan perundang-undangan di atasnya dan memiliki daya sentuh yang kuat dalam kehidupan masyarakat. Peraturan Daerah (Perda) dapat disusun karena peraturan Perundang-Undangan yang lebih tinggi dan mengakomodir kebutuhan khas daerah. ${ }^{25}$

\subsection{Bentuk Hak yang bisa Dilekatkan terhadap Bidang Tanah yang Berasal dari Proses Pengendapan Arus Sungai (Delta)}

Hak menguasai negara atas bumi, air, dan ruang angkasa dalam pelaksanaannya dapat dikuasakan kepada daerah-daerah swatantra (pemerintah daerah) dan masyarakat-masyarakat hukum adat sekedar diperlukan dan tidak bertentangan dengan dengan kepentingan nasional, menurut ketentuan-ketentuan peraturan pemerintah. Menurut Surat Edaran Menteri Negeri Agraria/Kepala Badan Pertanahan Nasional Nomor: 410-1293/1996 tentang Penertiban Statu Tanah Timbul dan Tanah Reklamasi menyebutkan: tanah yang hilang secara alami baik karena longsor, tertimbun, atau karena gempa bumi, atau pindah ke tempat lain karena pergeseran tempat maka tanah tersebut hilang dan haknya hapus dengan sendirinya. Selanjutnya pemegang haknya tidak dapat minta ganti rugi kepada siapapun dan tidak berhak menuntut apabila di kemudian hari di atas bekas tanah tersebut dilakukan reklamasi/penimbunan dan atau pengeringan. Mengenai kedudukan/status hukum dari tanah timbul itu sebagai tanah baru yang terjadi secara alami merupakan tanah negara. Menurut Pasal 1 Peraturan Pemerintah Nomor 8 Tahun 1953 tentang Penguasaan Tanah-tanah Negara bahwa: Tanah timbul adalah yang dikuasai penuh oleh negara. Tidak adanya peraturan perundang-undangan maupun peraturan teknis lainnya yang mengatur secara khusus mengenai tanah delta, maka tanah delta dapat dikategorikan sebagai tanah timbul (Aanslibbing). Tanah timbul (Aanslibbing) lazimnya hanya diberikan tiga macam hak untuk pendaftaran pertama kali hak atas tanah timbul, yaitu: Hak Milik (HM), Hak Pakai (HP), dan Hak Guna Bangunan (HGB).

Perolehan hak atas tanah timbul (aanslibbing) seperti tanah delta dapat dilakukan melalui permohonan hak. Permohonan hak atas tanah ini merupakan kegiatan untuk mendapatkan (memperoleh) tanah dengan cara mendaftarkannya pada Kantor Badan Pertanahan Nasional (BPN) Republik Indonesia Kabupaten/Kota setempat. ${ }^{26}$ Menurut Pasal 5 UUPA bahwa:

Hukum Agraria yang berlaku atas bumi, air dan ruang angkasa adalah hukum adat, sepanjang tidak bertentangan dengan kepentingan nasional dan negara, yang berdasarkan atas persatuan bangsa, dengan sosialisme Indonesia serta dengan peraturan-peraturan yang tercantum dalam Undang-Undang ini dan dengan peraturan perundang-undangan lainnya, segala

\footnotetext{
${ }^{24}$ Pulungan.

25 “Memahami Tahapan Dan Penerapan Peraturan Daerah Sesuai Kaidah,”Mampu, 2016, https://www.mampu.or.id/ kegiatan/pentingnya-pembuatan-dan-implementasi-perda-sesuai-kaidah-dan-kebutuhan.

${ }^{26}$ Jimmy Joses Sembiring, Panduan Mengurus Sertifikat Tanah (Jakarta: Visimedia, 2010).
} 
sesuatu dengan mengindahkan unsur-unsur yang bersandar pada hukum agama.

\section{PENUTUP}

Setelah mengkaji pengaturan tentang kedudukan hukum hak kepemilikan terhadap bidang tanah yang berasal dari proses pengendapan arus sungai (delta) dan hak apa yang dapat dilekatkan terhadap bidang tanah yang berasal dari proses pengendapan arus sungai (delta), dapat disimpulkan sebagai berikut:

1. Pegaturan yang mengatur tentang bidang tanah yang berasal dari proses pengendapan arus sungai (delta) belum diatur sehingga terdapat kekosongan hukum. Keberadaan tanah delta itu ada maka, tanah delta tersebut dapat dikategorikan sama seperti tanah timbul (aanslibbing); dan

2. Bentuk hak yang bisa dilekatkan terhadap bidang tanah yang berasal dari proses pengendapan arus sungai (delta) adalah:

a. Hak Milik

Apabila tanah mengalami pengendapan, maka dengan sendirinya terjadi Hak Milik dengan proses pertumbuhan yang memakan waktu melalui permohonan hak terlebih dahulu ke Kantor Badan Pertanahan Republik Indonesia Kabupaten/Kota setempat;

b. Hak Pakai

Hak ini dapat diberikan selama jangka waktu tertentu atau selama tanahnya dipergunakan untuk keperluan tertentu dengan cuma-cuma, dengan pembayaran atau pemberian jasa berupa apapun dan tidak boleh mengandung unsur-unsur pemerasan; dan

c. Hak Guna Bangunan

Hak Guna Bangunan pada tanah delta terjadi karena Penetapan Pemerintah karena tanah delta tersebut adalah tanah yang dikuasai oleh Negara. Hal ini dikuatkan dengan ketentuan yang ada dalam Pasal 21 Peraturan Pemerintah Nomor 40 Tahun 1996 Tentang Hak Guna Usaha, Hak Guna Bangunan, dan Hak Pakai atas tanah bahwa yang dapat diberikan Hak Guna Bangunan adalah Tanah Negara, Tanah hak Pengelolaan dan Tanah Hak Milik.

Peraturan Daerah (Perda) dapat disusun salah satunya adalah karena mengakomodir kebutuhan khas daerah oleh sebab itu Pemerintah Daerah (Pemda) sebaiknya merancang Peraturan Daerah (Perda) mengenai pengaturan dan pendaftaran atas bidang tanah yang berasal dari proses pengendapan arus sungai (delta).

Dalam memberikan suatu alas hak terhadap bidang tanah yang berasal dari proses pengendapan arus sungai (delta) perlu adanya penelitian yang cermat mengenai subyek, obyek, dasar penguasaannya (alas hak) dan bagaimana cara dalam perolehan serta pendaftaran atas bidang tanah yang berasal dari proses pengendapan arus sungai (delta) tersebut. Hal tersebut dilakukan agar dapat mencegah (preventif) timbulnya permasalahan/sengketa pertanahan di kemudian hari. 


\section{REFERENSI}

Akbar, Alif. "Studi Perubahan Garis Pantai Wulan Demak Jawa Tengah.” Jurnal Hukum 3, no. 7 (2013): 1.

Anam, Saiful. "Pendekatan Perundang-Undangan (Statute Approach) Dalam Penelitian Hukum." Siafulanam \& Partners: Advocates \& Legal Consultants, 2017. https:/www.saplaw.top/ pendekatan-perundang-undangan-statute-approach-dalam-penelitian-hukum.

Dewata, Mukti Fajar Nur, and Yulianto Achmad. Dualisme Penelitian Hukum Normatif Dan Empiris. Jakarta: Pustaka Pelajar, 2010.

Efendi, Jonaedi, Ismu Gunadi Widodo, and Fifit Fitri Luthfianingsih. Kamus Istilah Hukum Populer. Jakarta: Prenadamedia Group, 2016.

M.Hadjon, Philipus, and Tatiek Sri Djatmiati. Argumentasi Hukum. Yogyakarta: Gadjah Mada University Press, 2005.

Marzuki, Peter Mahmud. Penelitian Hukum. Surabaya: Kencana, 2011.

Mampu. "Memahami Tahapan Dan Penerapan Peraturan Daerah Sesuai Kaidah,” 2016. https:// www.mampu.or.id/kegiatan/pentingnya-pembuatan-dan-implementasi-perda-sesuai-kaidahdan-kebutuhan.

Merthokusumo, Sudikno. Hukum Dan Politik Agraria. Jakarta: Karunika Universitas Terbuka, 1988.

Paton, G. W. A. Textbook of Jurisprudence. English Language Book Society. London: Oxford University Press, 1972.

Pulungan, Rudiansyah. "Status Penguasaan Tanah Timbul (Aanslibbing) Di Kecamatan Rengat Kabupaten Indragiri Hulu.” Premise Law Jurnal 1, no. 2 (2013): 1. https://jurnal.usu.ac.id/ index.php/premise/article/view/8247.

Sembiring, Jimmy Joses. Panduan Mengurus Sertifikat Tanah. Jakarta: Visimedia, 2010.

\section{Peraturan Perundang-Undangan}

Kitab Undang-Undang Hukum Perdata (Burgerlijk Wetboek, Staatsblad Tahun 1847 Nomor 23)

Peraturan Pemerintah Nomor 40 Tahun 1996 Tentang Hak Guna Usaha, Hak Guna Bangunan, dan Hak atas Tanah

Peraturan Pemerintah Nomor 8 Tahun 1953 tentang Penguasaan Tanah-tanah Negara

Peraturan Pemerintah Nomor 16 Tahun 2004 tentang Penatagunaan Tanah

Surat Edaran Menteri Negara Agraria/Kepala Badan Pertanahan Nasional (BPN) Republik Indonesia Nomor: 410-1239 tanggal 9 Mei 1996 perihal Penertiban Status Tanah Timbul dan Tanah Reklamasi

Undang-Undang Nomor 12 Tahun 2011 Tentang Pembentukan Peraturan Perundang-Undangan Undang-Undang Nomor 5 Tahun 1960 tentang Peraturan Dasar Pokok-Pokok Agraria 